\title{
HISTORY OF DEVELOPMENT AND UP-TO-DATE TENDENCY
}

\author{
CMishalov V. D. ${ }^{1}$, Kryvda G. F. 2, Bachinskiy V. T. ${ }^{3}$, Voichenko V. V. ${ }^{4}$ \\ ${ }^{1}$ Shupyk National Medical Academy of Postgraduate Education, \\ Forensic Medicine, department of forensic medicine \\ ${ }^{2}$ Odessa State Medical University \\ ${ }^{3}$ Bukovina State Medical University \\ ${ }^{4}$ Dnipropetrovsk Regional Bureau of forensic examinations
}

Resume. The article examines the historical information regarding the use of dermatoglyphics during the identification of an unknown person. Outlined by new perspectives of using modern developments in the field of forensic criminology in studying skin patterns and the development of diagnostic algorithms common phenotypic traits of man.

Keywords: forensic science, dermatoglyphics.

Study images of skin on the inner the hand have their origins since ancient times. According to historical sources, in the ancient Babylon and China fingerprints done on clay tablets and stamps, and in the fourteenth century in Persia by fingerprints signing various government documents. This indicates that even at that time fingerprint is seen as a unique human characteristic [1].

As a result of the accumulation of knowledge in the study of papillary patterns of palms, was established science, which is called "dermatoglyphics". One of the first scientific reports of dermatoglyphics appeared in 1684. It was a description of scallops skin and sweat pores made by the British anatomist Nehemiah Grew. In 1685 Howard Bidloo in the book of human anatomy presented a picture and description of skin scallops fingers. Czech biologist Ian Purkine in 1823 gave the first classification of variations finger patterns. However, the "father" of dermatoglyphics is considered Francis Galton. In 1892, in his monograph about fingerprints «Finger prints», Galton summarizes outcome of in this area and establishes basic principles of dermatoglyphics: immutability of finger patterns throughout the life, personality and simple possibility of classification into three types - arches, loops and curls $[1,2]$.

Nowadays, possibilities and perspectives dermatoglyfics in medicine dedicated many body scientific papers. Interest in this field of medical knowledge is determined by the huge volume of information held in papillary pattern. Areas of use the dermatoglyphics are quite varied: clinical medicine (psychiatry, dermatology, pediatrics, medical genetics and other), psychophysiology (professional selection, sports medicine), forensic medicine (determination of paternity, maternity and spoofing of children, identification of any person, determining the whole of a part). For skin patterns possible diagnosis of many hereditary diseases, chromosomal aberrations (Down Syndrome, Shershevsky -Terner syndrome), genomic disorders (phenylketonuria, heart deffects, polycystosis ovary), diseases with hereditary predisposition (epilepsy, schizophrenia, addiction, diabetes, peptic ulcer, asthma, psoriasis) and many others, including infectious diseases that have a hereditary etiopathogenetical component (tuberculosis, leprosy, viral hepatitis B) [3]. The ability to diagnose diseases till the clinical period - the most important task in the study of dermatoglyphic. Interconnection of papillary patterns with constitutional characteristics and peculiarities the psyche used during the professional selection. The most successful such opportunities of dermatoglyphics used in sports medicine in which training of sportsman is going from early childhood (swimming, gymnastics, figure skating and so on.). It is proved that persons with the predominance the arc patterns that best reveal themselves in sports requiring strength and endurance (heavy lifting, marathon), while the men with a predominance the curl bigger propensity for gaming or related with high coordination movements sports (sprint running, table tennis, diving) [6,7].

Prospects of application dermatoglyphics in forensic medicine associated with the Identification of a person, the establishment of paternity, maternity and substitution children.

Identification of the person during many years been one of the most relevant sections of forensic medicine and criminology. The most famous and widely used method is fingerprinting. The main issue which decided in the course of the fingerprint examination is that whether left the fingerprint found at the scene, by a specific person. In the event that the range of persons which investigated are not established, there is a need to give a general description of unknown person. In this connection there are the following tasks: determining growth, age and sex unknown person, especially its occupation, etc. [4,5].

In that time in independent partition isolated the criminalistics dermatoglyphics as the direction of fingerprinting, which aims to determine the characteristics of criminals and persons suspected of committing crimes by of papillary pattern. And also conducting research in determining disputed paternity and identification of unidentified corpses. Quite a long time used in criminology developed in dermatohlifics criteria volyar relief (of papillary lines), namely of curls spiral patterns to determine the arm, which was left. According to the rule Osvaldo Miranda Pintau in the right hand prints flows of papillary lines curled counterclockwise, and left - clockwise. The exception is the index finger, is dominated radial type. 
Diagnostic possibilities of dermatoglyphics far exceed the tasks which can solve the fingerprinting. The solution of many diagnostic tasks in dermatohlifics possible based on biological (medical) knowledge possessed by forensic experts. Among the large number of diagnostic problems solved by forensic experts, currently the following: diagnostics of biological nature of trail, diagnosis of pertaining to a species, determining racial and gender will determine whether there is a person right handed or left-handed, determining the age, height, body structure , the definition of human diseases, identification of behavioral characteristics and others.

Ascertainment the biological nature of the track, during the dermatoglyphics study possible with papillary pattern piece. For typical structure of of papillary lines, the availability of certain signs and white lines, in poroskopic and edzheoskopic signs can solve this problem. This problem is most relevant in the possible falsification of traces of hands and can be resolved through Express- research sweatfat substances in the track, the test sample using a flame. Combustion of organic substances accompanied by a characteristic odor, synthetic material and is not accompanied by reflow.

Research of scientists established that the regularity of dermatohlific patterns around the globe, typical for elements of a comb (finger, palmar, plantar) and rhombic skin. Thus, in the representatives of the European race the loop patterns are more common than curls, geographical distribution which increases from north to south and from west to east. Diagnosis by gender based on high frequency the arc and ulnar loops in women curl patterns and delta indexes - in men. Some disputed data on the frequency of "white lines" of men and women. According to forensic medics, they are more common in women which is considered as differential signs in determining sex. Regarding cicatricial changes - they indicate the number of past years and more present on the finger cushions distal phalanx of men.

In terms of hereditary the constitution of the body composed of historical system responsible for the intensity of growth and metabolism genes. Research has established that the three main types of of papillary patterns correspond to three main types of constitution. Yes, normostenic type corresponds the loop type pattern in 55-60\% hypersthenic -in $20-25 \%$ curls and asthenic type corresponds the arcus - in $10-15 \%$.

With specific regard to length of the body, then the tall persons observed an increased frequency the arc patterns and reduced the loop patterns. Thus, men with the syndrome Klinefelter (tall) increased frequency the arc patterns, compared with healthy men and women with the syndrome Shershevsky- Terner (usually undersized) reduced frequency the arc patterns and increased frequency loop and curl patterns and reduced width of the crest.

In determining whether a person is right-handed or left-handed by dermatohlifs, it was found unevenly distributed patterns of right-handers and left-handers. Thus, in the right-handed curls patterns are more common on the right hand, loop on the left; left-handed - curl patterns prevail on his left hand,loop on the right.

At research of of behavioral and mental characteristics of man has been found correlation between dermatoglyphics characteristics and peculiarities of the psyche. The obtained data indicate that people with curl patterns observed resilience and stubbornness, the carrier of the loop patterns - mental and emotional flexibility but insufficient focus on achieving goals. People with prevailing arc characteristic patterns of occultness, suspicion. In extroverts (choleric, sanguine) dominated the loop patterns with a high crest account, in phlegmatics - low crest account $[8,9]$.

Thus, the study of dermatoglyphics characteristics of different groups of people is a perspective direction of modern forensic criminology in terms of the development of algorithms of identification unknown persons in cases examination of massive of victims or fragmented corpses.

\section{Referenses}

1. Hyt G. L. Dermatoglyphics in antorolohyy / G. L. Hyt, I. G. Shyrobokov, I. A. Slavolyubova // Otv. Ed. IG Shyrobokov - SPb .: Nestorystoryya, 2012, 376 p. (in Russian)

2. V. N. Zvyagin Dermatoglyphics in forensic medicine / 1989, 78 p.(in Russian)

3. Bozhchenko A. P. Opportunities and prospects dermatoglifiks in medicine / A. P. Bozhchenko, I. A. Tolmachev // Military medical magazine, 2008. T.329. №12, p.19-24. (in Russian)

4. Bozhchenko A. P. Opportunities and prospects of forensic dermatoglyphics / A. P. Bozhchenko, I. A. Tolmachev, S. A. Moiseenko, V. V. Kolkutin // Sud. med. expert of, 2009. - №3. - p. 33-36. (in Russian)

5. Bozhchenko A.P. Dermatoglyphics fingers in the aspect of forensic identifekation of person / A. P. Bozhchenko, I. A. Tolmachev // Sud. med.expert of, 2009. - №2. - p.25-29. (in Russian)

6. Sergienko L. P. Metods of sports Genetics: Dermatoglyphic analysis of human fingers / L. P. Sergienko, V. M. Lishevskaya // Pedagogy, psihologiy and medico-biologic problems fiz. and sport, 2010. №2. p.148-154 (in Ukrainian)

7. Abramova T. F. Finger dermatoglyphics and physical abilities, 2003 (in Russian)

8. Sokolova O. A. Diagnostics fingerprinting: monograph, M .: Yurlitinform, 2013, p.192 .(in Russian)

9. Isyutin- Fedotko D. V. Kryminalistic dermatoglyphics - section of trasologic? / D. V. Isyutin- Fedotko // News Zaporizen nat. univers. - 2011. - №2. (in Russian) 


\title{
ДЕРМАТОГЛІФІКА: ІСТОРІЯ РОЗВИТКУ І СУЧАСНІ ТЕНДЕНЦЇ̈
}

\author{
Мішалов В. Д., Кривда Г. Ф., Бачинський В. Т., Войченко В. В.
}

Резюме. У статті розглянуто історичні відомості стосовно використання дерматогліфіки при проведенні ідентифікації невідомої особи. Накреслено нові перспективи використання сучасних розробок в галузі судово-медичної криміналістики у вивченні шкірних візерунків та розробки алгоритмів діагностики загальних фенотипічних ознак людини.

Ключові слова: судова медицина,дерматогліфіка.

\section{ДЕРМАТОГЛИФИКА: ИСТОРИЯ РАЗВИТИЯ И СОВРЕМЕННЫЕ ТЕНДЕНЦИИ}

\author{
Мишалов В. Д., Кривда Г. Ф., Бачинский В.Т., Войченко В. В.
}

Резюме. В статье рассмотрены исторические сведения об использовании дерматоглифики при проведении идентификации неизвестных лиц. Намечены новые перспективы использования современных разработок в области судебно-медицинской криминалистики при изучении кожных узоров и разработки алгоритмов диагностики общих фенотипических признаков человека.

Ключевые слова: судебная медицина, дерматоглифика.

UDK $340.6+343$

\section{NEURAL NETWORKS AND PERSPECTIVES OF THEIR USE IN FORENSIC MEDICINE}

\author{
CKozan N. M. \\ SHEE «Ivano-Frankivsk National Medical University»
}

\begin{abstract}
This paper presents the trends and tendencies of modern computer processing data obtained during forensic investigations. Examined the system of artificial neural networks, principles and characteristics of their work. Prospects using artificial neural networks when dermatoglyphics data processing research.

Keywords. Forensic medicine, neural networks.

Introduction. One of the open questions in forensic medicine, remains a question posed by the problem of identifying an unknown person and conduct identification of corpses of unknown persons, fragmented and impersonal corpses. Today, the most popular method for DNA identification, which, despite the initial accuracy of results is expensive and all available diagnostic methods. Therefore, in recent years all dermatoglific method as more popular,simple and cheaper to use. Studying thein heritance of dermatic patterns of fingers and toes westerlies with goal to ascertainment congeniality at forensic examination unknown persons. Dermatoglific method to be able has marked advantage in questions of determination relationship as another genetic methods. In particular in availability computer program it can be widespread routine method of diagnosis in forensic medicine. Unfortunately, today analogous programme for the present is still not exist. Its closest analogues can be fingerprint computer programs which used in crymynalistic whith purpose automated fingerprint identity. Similar programs today already exist. With appropriate software revision, they probably could be useful in medical genetics and anthropology. In particular, Fokyn V.A. and co-author. (2002) was created program "KYBERINFORM" Medical Genetic purpose to analyze the main dermatoglyphics parameters that can complement the programs implemented their automatic recognition, such as kriminalistychnoyi fingerprint program "Songdo" (version 4.2 of "Pathfinder") which is widely used for Forensic purposes since the early 90's. and well proven. This program "Songdo" capable, in particular, automatically identify and classify basic types of papillary patterns terminal phalanges of both hands. She distinguishes 19 types of such pictures and classifies them into arches, loops and curls on System Galton-Henry. Results of identifying of each person can be seen on the computer screen. To push off on these images, it is possible to assess quantitatively the degree of asymmetry of the right and left hands, to compute basic indices for the control and research groups, which may be useful for the mass population anthropometric and genetic research [1]. Last years big popularity obtaind artificial neural networks base on which are created identification programs, including and forensic [2]. The aim of our study was to investigate the current state of computer identification applications, such as artificial neural networks. Results and discussion. An artificial neural network (ANN) - a software - hardware complex built on a mathematical model that resembles the principle of operation of biological neural networks This concept formed the study of processes occurring in the brain [3]. An artificial neural network (the neural network) is a system of connected and interacting processors (neurons). Neuron (basic neural network element) is a simple computer processor which can handle perceive and transmit simple signals (information). When you combine a large number of neurons in a network, the system can solve non-trivial task. Neural network equally well appropriate for solving both linear and nonlinear problems. Neural network, depending on your architecture [4] can be divided by level of difficulty. The basic
\end{abstract}

